\title{
The Criteria of Sustainability Economic and Social of Existance Geothermal Power Plant to Surrounding Community (Case study on geothermal power plant at Sukabumi, West Java)
}

\author{
Raity Arief Hidajat ${ }^{1}$, Suyud Warno Utomo ${ }^{2}$, Iwa Garniwa ${ }^{3}$, Mahawan Karuniasa ${ }^{4}$ \\ $\underline{\text { raity.arief@gmail.com }}$, $\underline{\text { suyudwarno@gmail.com }{ }^{2}}, \underline{\text { iwa@ee.ui.ac.id }}{ }^{3}, \underline{\text { mahawancac@yahoo.com }^{4}}$ \} \\ School of Environmental Science, Universitas Indonesia ${ }^{1}$, School of Environmental Science, \\ Universitas Indonesia ${ }^{2}$, Electrical Engineering Department, Faculty of Engineering, Universitas \\ Indonesia $^{3}$, School of Environmental Science, Universitas Indonesia ${ }^{4}$
}

\begin{abstract}
Recently, electricity consumption in Indonesia continue to increase rapidly along with the increase in technology, economic growth and also the increase in the population. One potential source of electrical energy comes from geothermal energy, where Indonesia has enormous potential. In this research the aspects studied is sustainable development on economic and social as research variable, where the existence of geothermal power plants is expected to have a positive impact on the sustainability of economic and social of the surrounding communities. Locus of this research is Geothermal Power Plant that operated at Kalapanunggal sub-district, which is located in Sukabumi District, West Java. The method used is Analytical Hierarchy Process (AHP) to obtain assessment criteria. From the AHP results, the economic criteria from existence geothermal power plant is regional income from production bonus, and social criteria is the use of labour and local products.
\end{abstract}

Keywords: geothermal, sustainable development, community

\section{Introduction}

Population and economic growth make demand for electricity supply continue to increase. This is what makes the development of renewable energy power plants considered a national need that can no longer be delayed. Electrical energy has now become a major need in people's lives, the need for electricity in Indonesia which continues to increase rapidly along with the increase in development, economic growth and also the increase in the population in Indonesia.

One potential source of electrical energy is geothermal energy, where Indonesia has enormous potential source where until the end of 2016 there were at least 331 geothermal energy source locations throughout Indonesia, with a potential of 28,579 MWe and estimated reserves around 17,506 MWe and installed capacity (Ministry of Energy and Mineral Resources, 2017).

The connection with sustainable development is how to optimize the presence of this future power plant to improve the economic life and social life of the surrounding community.

Since 1987 the world has introduced the concept of sustainable development by the World Commission on Environment and Development, chaired by Gro Harlem Bruntland, the 
Norwegian Prime Minister at the time. This commission produced a report known as "The Brundtland Report" which added economic aspects to the ecological and social aspects. Sustainable development is a development process that has the principle of meeting current needs without compromising the fulfillment of future generation's needs. The factor that must be faced to achieve sustainable development is how to improve environmental destruction without sacrificing the needs of economic development and social justice. The 2005 World Summit outlined that sustainable development consists of three main pillars, namely economic, social, and interdependent and strengthening environments.

The existence of a large activity in an area is highly expected to have a positive impact that can be felt by the surrounding community. The Company carries out its business activities in the field are required to carry out social and environmental responsibility, however aspects that are really needed by the community according to their needs have not been clearly identified. For this reason, this study aims to capture the needs of the community based on the objective view of expert resource persons from both the government in charge of geothermal fields, academic, local regional leaders and references from other sources.

The locus was a geothermal power plant on Kalapanunggal sub-district, located in Sukabumi district, West Java. The population of Kalapanunggal Sub-district according to the results of the June 2010 population census was 55,587 persons, and the economic potential is agriculture, plantations, goat farm and arts. The Kalapanunggal Sub-district originally consisted of four regions which included: Kalapanunggal region, Cikidang region, Kabandungan region and Parakansalak region. The area of Kalapanunggal Sub-district is 7,501.37 hectares and consists of 7 villages, 56 citizens association, and 210 neighborhood association. The location of Kalapanunggal Sub-district is on the Gunung Salak area which has a height of between 5001,000 meters above sea level.

\section{Methods}

Recognizing the importance of consideration economic and social as comprehensive aspects in the concept of sustainable development. We identified the criteria related to the economy and social based on interviews with expert resource persons, consisting of government, sub-district heads, academic and references from the Global Reporting Initiative.

These parameters are processed by the Analytical Hierarchy Process (AHP) method to obtain assessment criteria and alternative choices. AHP was developed by Prof.Thomas L. Saaty as a decision making algorithm for multi-criteria problems. The multi-criteria problem in AHP is simplified in the form of a hierarchy consisting of 3 main components, namely the goal of decision making, assessment criteria and alternative choices. After the multi-criteria problem is modelled in a hierarchy, it can begin the pairwise comparison stage that will be used when searching for the weighted criteria and alternative weights for each assessment criterion. Pairwise comparisons are made based on subjective preferences of decision making.

AHP is often used as a method of solving problems compared to other methods, because AHP makes broad and unstructured problems into a model that is flexible and easy to understand, AHP also solves complex problems through a system approach. 
Table 1. Table Scale 1-9 Saaty

(Source: Decision Making with the Analytic Network Process)

\begin{tabular}{cc}
\hline Scale & Example \\
\hline 1 & Equal Importance \\
2 & Weak \\
3 & Moderate importance \\
4 & Moderate plus \\
5 & Strong importance \\
6 & Strong plus \\
7 & Very strong demostrated importance \\
8 & Very, very strong \\
9 & Extreme importance \\
\hline
\end{tabular}

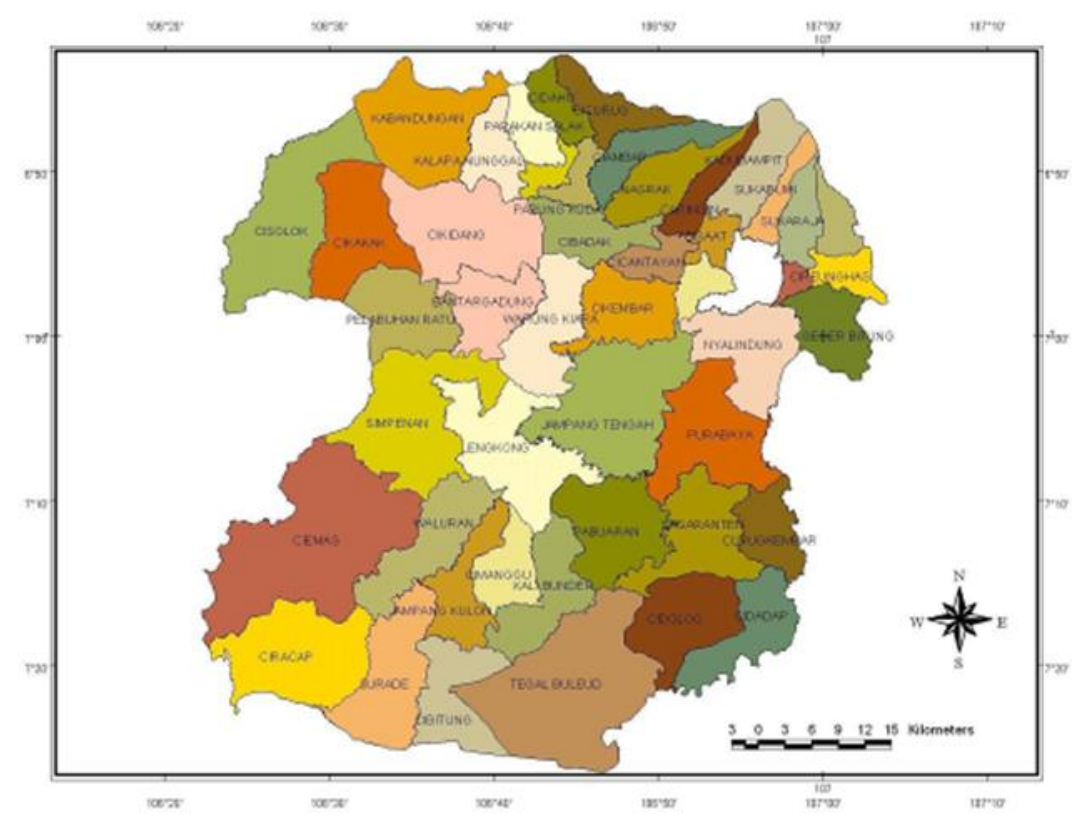

Fig. 1. Map of Sukabumi District

The AHP method requires interaction with decision makers. Through interaction, the AHP will process it into a solution in the form of a priority scale for a number of alternatives.

This study aims to establish the right criteria related to the economic and social existence of a power plant to the surrounding community and has not yet led to a decision on a choice. 


\section{Results and Discussion}

Economic and social criteria are based on interviews with several expert resource persons who are have a connection, experience and interest in the existence of a geothermal power plant in the Kalapanunggal sub-district. Expert resource person include:

a. The Government, by the Sub Directorate of Engineering and Environment of the Directorate General of New and Renewable Energy and Energy Conservation (EBTKE)

b. Academic in the field of sustainability study and reporting from Bandung Institute of Technology (ITB).

c. Local government, head of Kalapanunggal sub-district (Camat).

d. Reference to the G4 Sustainability Reporting Guidelines from the Global Reporting Initiative (GRI).

Interview was conducted to each expert resource person to get their views on important criteria related to the economic and social aspects of the existence geothermal power plants in the Kalapanunggal sub-district based on their observation, experience and expertise.

\subsection{Create a hierarchy structure}

From the results of identifying the criteria of each resource person, a hierarchical model is drawn as illustrated below for both economic and social aspects:

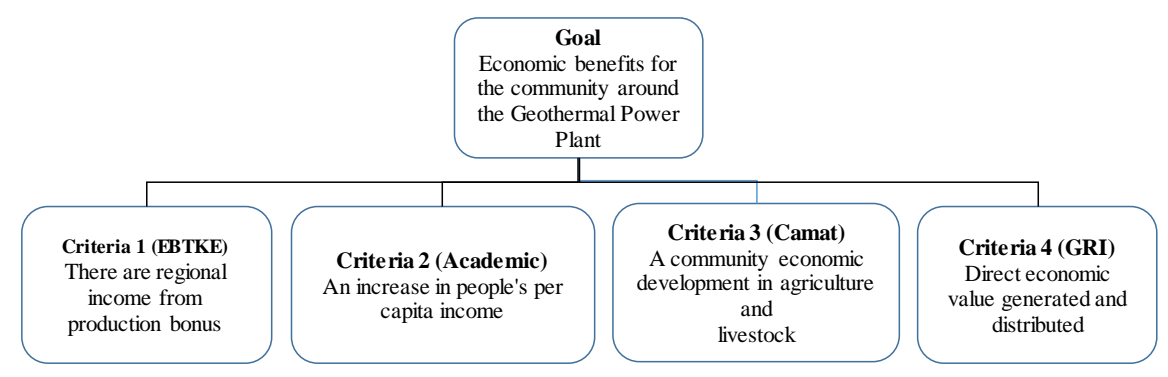

Fig. 2. AHP hierarchy model for economic criteria

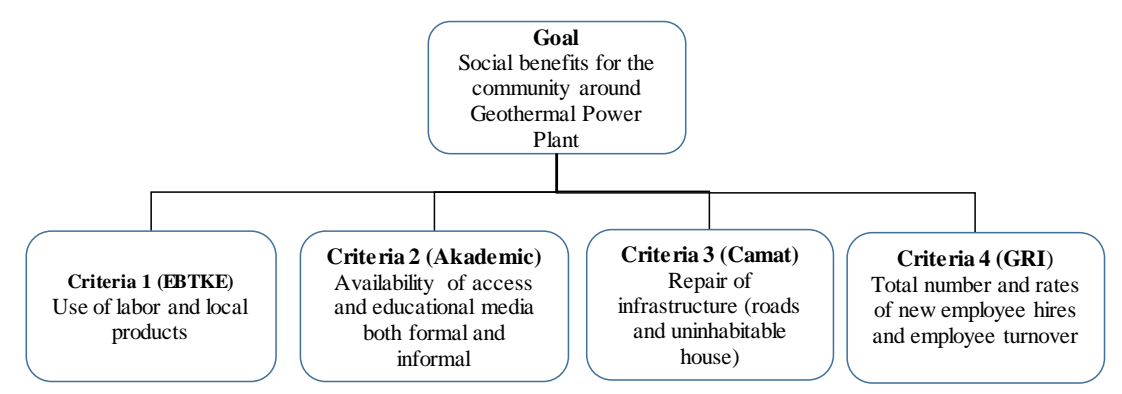

Fig. 3. AHP hierarchy model for social criteria 


\subsection{Pairwise comparison and consistency ratio}

Pairwise comparison is to determine the comparison between one criteria with other criteria which is then modeled in a pairwise comparison matrix and the matrix goes through a normalization process to get priority order.

Table 2. Pairwise comparison for economic criteria and normalization

$\left.\begin{array}{lcccc}\text { Criteria 1 } & \text { Criteria 1 } & \text { Criteria 2 } & \text { Criteria 3 } & \text { Criteria 4 } \\ \text { Criteria 2 } & 1 & 4 & 2 & 4 \\ \text { Criteria 3 } & 0.25 & 1 & 0.33 & 0.5 \\ \text { Criteria 4 } & 0.5 & 3 & 1 & 2 \\ \text { Sum Result } & 0.25 & 2 & 0.5 & 1 \\ 2.00 & 10.00 & 3.83 & 7.50\end{array}\right]$

\begin{tabular}{l|cccc}
\multicolumn{1}{l}{} & Criteria 1 & Criteria 2 & Criteria 3 & Criteria 4 \\
Criteria 1 & 0.50 & 0.40 & 0.52 & 0.53 \\
Criteria 2 & 0.13 & 0.10 & 0.09 & 0.07 \\
Criteria 3 & 0.25 & 0.30 & 0.26 & 0.27 \\
Criteria 4 & 0.13 & 0.20 & 0.13 & 0.13 \\
Sum Result & 1.00 & 1.00 & 1.00 & 1.00
\end{tabular}

From the normalization calculation, the priority vector of economic is obtained:

Table 3. Priority vector of economic

\begin{tabular}{cc}
\hline Criteria & Priority \\
\hline Criteria 1 - regional income from production bonus & $49 \%$ \\
Criteria 2 - An increase in people's per capita income & $9 \%$ \\
Criteria 3 - A community economic development in & $27 \%$ \\
agriculture and livestock & \\
Criteria 4 - Direct economic value generated and & $15 \%$ \\
\hline distributed & \\
\hline
\end{tabular}


Consistency Index (CI) is 0.0202 and Consistency Ratio (CR) is 0.02 , so the above assessment can be accepted because it is smaller than 0.1 .

Table 4. Pairwise comparison for social criteria and normalization

Criteria $1 \quad$ Criteria $2 \quad$ Criteria $3 \quad$ Criteria 4

$\left.\begin{array}{l|cccc}\text { Criteria } 1 & 1 & 2 & 4 & 2 \\ \text { Criteria } 2 & 0.50 & 1 & 0.50 & 0.50 \\ \text { Criteria } 3 & 0.25 & 2 & 1 & 2 \\ \text { Criteria } 4 & 0.25 & 2 & 0.50 & 1 \\ \text { Sum Result } & \mathbf{2 . 0 0} & \mathbf{7 . 0 0} & \mathbf{6 . 0 0} & \mathbf{5 . 5 0}\end{array}\right]$

$\left.\begin{array}{lrrrrr}\multicolumn{1}{c}{\text { Criteria 1 }} & \text { Criteria 2 } & \text { Criteria 3 } & \text { Criteria 4 } \\ \text { Criteria 1 } & 0.50 & 0.29 & 0.67 & 0.36 \\ \text { Criteria 2 } & 0.25 & 0.14 & 0.08 & 0.09 \\ \text { Criteria 3 } & 0.13 & 0.29 & 0.17 & 0.36 \\ \text { Criteria 4 } & 0.13 & 0.29 & 0.08 & 0.18 \\ \text { Sum Result } & \mathbf{1 . 0 0} & \mathbf{1 . 0 0} & \mathbf{1 . 0 0} & \mathbf{1 . 0 0}\end{array}\right]$

From the normalization calculation, the priority vector of social is obtained:

Table 5. Priority vector of social

\begin{tabular}{cc}
\hline \multicolumn{1}{c}{ Criteria } & Priority \\
\hline Criteria 1 - Use of labor and local products & $45 \%$ \\
Criteria 2 - Availability of access and educational media both & $14 \%$ \\
formal and informal & $24 \%$ \\
Criteria 3 - Repair of infrastructure (roads and uninhabitable & \\
house) & $17 \%$ \\
Criteria 4 - Total number and rates of new employee hires and & \\
employee turnover &
\end{tabular}


Consistency Index (CI) is 0.0804 and Consistency Ratio (CR) is 0.09 , so the above assessment can be accepted because it is smaller than 0.1 .

\section{Conclusion}

Community leaders, policy makers and expert resource persons play an important role in reading the situation of the community against economic and social needs. This can be seen from the results of discussions with community leaders and policy makers in the area of research carried out. Community leaders, policy makers and expert resource person due to their interaction with the community can know for certain what the community needs more objectively. Community leaders, policy makers and expert resource person can play a role as a liaison to companies in their area to provide input on what economic and social programs are appropriate for the surrounding community so the level of community welfare can increase and the existence of the company can be sustained in the area.

Based on the AHP calculation above, the criteria for economic that are a priority to be carried out by geothermal power plant at Kalapanunggal sub-district is how to generate regional income from the production bonus given by the power plant to the community.

Criteria the social aspect that becomes a priority is how to utilize local labour and local products from surrounding communities at Kalapanunggal sub-district. Increased use of local labour and local products is directly correlated to the improvement of the community's economy.

AHP calculation can be used to compile an index of the sustainability of economic, social aspects of the existence of several geothermal power plants in a region by continuing the calculation of pairwise comparison up to the choice hierarchy.

\section{References}

[1] Rogers, P.: An Introduction of Sustainable Development. Glen Educational Foundation, Inc (2008)

[2] Pravitasari, A. M et all.: Developing Local Sustainability Index (LSI) at Village Level in Jambi Province. ResearchGate (2018)

[3] Saaty, T. L.: Pengambilan Keputusan Bagi Para Pemimpin Proses Hierarki Analitik untuk Pengambilan Keputusan dalam Situasi yang Kompleks. PT Dharma Aksara Perkasa (1991)

[4] Padmowati, R. L. E.: Pengukuran Index Konsistensi Dalam Proses Pengambilan Keputusan Menggunakan Metode AHP. Seminar Nasional Informatika (2009)

[5] Badan Geologi ESDM.: Pemutakhiran Basis Data Potensi Panas Bumi Indonesia. ESDM (2017)

[6] Kaufmann, R., \& Cleveland, C.: Environmental Science. Mc Graw-Hill International (2008)

[7] Lubis, A. : Energi Terbarukan dalam Pembangunan Berkelanjutan. Jurnal Teknologi Lingkungan (2007)

[8] Sneddon, C.: Sustainable development in a post-Brundtland world. Ecological Economics 57 (2006).

[9] Cunningham, W. P.: Environmental Science A Global Concern (10th edition). Mc Graw-Hill (2008).

[10] Miller, T.: Environmental Science. Cengage Learning (2016)

[11] Lucat Sneddon, C.: Sustainable development in a post-Brundtland world. Ecological Economics 57 (2006) 
[12] Cunningham, W. P.: Environmental Science A Global Concern (10th edition). Mc Graw-Hill. (2008)

[13] Miller, T.: Environmental Science. Cengage Learning (2016).

[14] Lucato, W. C.: Measuring the Sustainability of a Manufacturing Process. A Conceptual Framework. Sustainability MDPI (2017)

[15] United Nation.: The Sustainable Development Goals Report 2018, United Nations (2018)

[16] Saaty T. L \& Vargas L. G.: Decision Making with The Analytic Network Process, Springer Science Business Media. (2006) 